\title{
Epilithic Microalgae Isolated from Biofilm on Borobudur Temple Stone
}

\author{
Debora Christin Purbani ${ }^{1 *}$, Ade Lia Putri ${ }^{1}$, Moh. Habibi ${ }^{2}$ \\ 1) Research Center for Biology, Indonesian Institute of Sciences (LIPI) 16911, Bogor, Indonesia. \\ 2) Borobudur Conservation Office, Indonesian Ministry of Education and Culture 56553, Magelang, Indonesia.
}

Submitted: 31 August 2020; Accepted: 17 November 2020; Published: 15 December 2020

\begin{abstract}
Borobudur Temple is a historical heritage building located in an open area and made of porous building materials (stone materials). This condition makes the Borobudur Temple susceptible to various problems related to degradation and weathering. Biodeterioration of Borobudur Temple may be caused by activities of living organisms present in the biofilm of stone. Continuous monitoring and evaluation need to be carried out by observing and isolating the growth of micro-organisms, including epilithic microalgae. Therefore, this study aims to isolate and identify epilithic microalgae from the biofilm on Borobudur Temple stones. Epilithic microalgae were isolated to obtain a uni-algae and maintained under culture conditions. The morphological of microalgae were observed using light microscopy, while the 18S rRNA gene sequence determined the molecular identification of microalgae for eukaryotic and 16S rRNA sequence for prokaryotic. A total of nine epilithic microalgae were successfully isolated from the biofilm of Borobudur Temple stones. The isolated were identified as Ankistrodesmus falcatus, Tetraselmis cordiformis, Pseudendoclonium arthropyreniae, Anabaena cylindrica, Nostoc gelatinosum, Oscillatoria limnetica, Messastrum gracile, Stigeoclonium aestivale, and Scenedesmus acuminatus. This is the first study for the identification of microalgae from Borobudur temple stones. The isolates will be collected and will be used as a source for further study.
\end{abstract}

Keywords: $16 \mathrm{~S}$ rRNA gene, 18S rRNA gene, epilithic algal, molecular identification, phylogeny, subaerial

\section{INTRODUCTION}

Borobudur Temple is located in Borobudur Village, Borobudur District, Magelang Regency, Central Java Province. This historical heritage temple compound was built in an open area on a modified hill, with a height of 265 meters above sea level, with a length of 121.66 meters, width 121.38 meters, and a height of 34.50 meters. The structure of the Borobudur Temple consists of nine terraces and a main stupa at the top. There are six rectangular terraces and three circular terraces, covering the Kamadhatu, Rupadhatu, and Arupadhatu levels. Borobudur Temple built using the andesite stone material from rivers around the Borobudur Temple with a total of \pm 2,000,000 pieces of stones (Banindro, 2015; Salazar, 2018).

\footnotetext{
*Corresponding author

Tel.: +6287837107877

Email: deborachristin22@gmail.com

(C) 2020, J. Tropical Biodiversity Biotechnology (CC BY-SA 4.0)
}

The restoration of Borobudur Temple has been carried out twice, the Dutch East Indies government carried out the first restoration under the leadership of Van Erp, and the second restoration was carried out by the Indonesian government chaired by Soekmono (Voûte \& Voute, 1973; Gunarto, 2007; Banindro, 2015). Rehabilitation of Borobudur Temple has also been done after Mount Merapi's eruption in 2010 to clean up volcanic ash, which is chemically acidic and can damage this historic temple stone. Demolition of stone blocks has been carried out to improve the clogged water and drainage system, which is clogged with volcanic dust mixture mixed with rainwater, followed by reforestation and planting of trees in the surrounding environment to stabilize the temperature (Yulianto et al., 2013; Khoirunnisa, Warsono, \& Suryaningsih, 2014). After the Borobudur Temple has been restored and rehabilitated, it does not mean that the temple maintenance has been completed. There is no 
guarantee that the Borobudur Temple is free from damage, degradation, and weathering processes. Therefore, continuous monitoring and evaluation need to be carried out by observing and isolating the growth of micro-organisms, including epilithic microalgae covered on Borobudur Temple stones.

Epilithic microalgae are part of a group of peripheral microalgae that live attached to various substrates such as rocks/stones, corals, gravel, and other hard objects. The development and ability of epilithic microalgae are very dependent on the presence and condition of the substrate. Microalgae attached to temple stone are more permanent than microalgae attached to a living substrate because the living substrate will experience development and death. In contrast, in the substrate, inanimate objects do not experience changes such as damage or death. The presence of epilithic microalgae on surfaces over time can cause substantial damage, including physicochemical damage and aesthetic discoloration of stone objects such as facades of buildings and monuments (Garside, 2010; Bertuzzi et al., 2017; Matteucci et al., 2019).

Several studies have been reported that eukaryotic green micro-algae are the dominant organisms on the biofilm of monumental stones of temperate regions, where microalgae like the Cyanophyta group predominantly occur on similar substrates in the tropics (Song, Kim \& Lee, 2012; Keshari \& Adhikary, 2013; Nakajima, Hokoi \& Ogura, 2015; Villa et al., 2016). Research on the isolation and identification of microorganisms associated with moss on the Surface of the Borobudur Temple Stone has been carried out on the Actinomycetes group, as one of the monitoring and exploration of microorganism biodiversity in Borobudur Temple (Putri, Purbani, \& Habibi, 2020). However, studies of epilithic microalgae isolated from biofilms in Borobudur Temple stones have never been reported. Studies on microbial populations living, including epilithic microalgae on stones of Borobudur Temple, need to be done as a starting point for successful conservation management and control. One of the most important steps in studying the epilithic microalgae ecology of Borobudur Temple stones is to identify the microalgae involved in biological damage/ biodeterioration. Therefore, this study aims to isolate and identify epilithic microalgae from the biofilm on Borobudur Temple stone, as a database that can complement studies on micro-organism in particular that can weather and reduce the aesthetic value of temples in Indonesia.

\section{MATERIALS AND METHODS}

\section{Materials}

The materials were used for this study: a sterile swab, scalpel, screw cap and bottles, Pasteur pipette, object and cover glass, rubber bulb, microscope (Olympus CKX41 and Olympus BX5), Olympus DP26 cameras, corning well cell, fluorescent lamps, shaker incubator, shaking bath, centrifuge, vortex mixer, microtube $2.0 \mathrm{ml}$, beat bitter, micropipette and tips, thermal cycler (PCR), electrophoresis apparatus, UV transilluminator, Gel Doc, BG11 medium, Genomic DNA mini kit (Plant) Geneaid, Go Taq Green kit, and universal primer 18S rRNA and $16 \mathrm{~S}$ rRNA gene.

\section{Methods}

Samples were collected from the exposed biofilm stone surfaces of the different tiers of Borobudur Temple by gently scrapping the surfaces of stone with a sterile swab and scalpel. Each sample was placed into the BG11 medium (Keshari \& Adhikary, 2013). Epilithic microalgae were isolated to obtain a uni-algae culture using the capillary micro-pipetting method under the light microscope (Olympus CKX41). The culture was maintained for 10-14 days at $25^{\circ} \mathrm{C}$ below $30 \mu \mathrm{mol} \mathrm{m}^{-2} \mathrm{~s}^{-1}$ fluorescent light with $12 \mathrm{~h}$ light cycle: $12 \mathrm{~h}$ dark in a shaker incubator (Anderson, 2005; Barsanti \& Gualtieri, 2014). Morphological characteristics of epilithic microalgae were observed regularly under a microscope using Olympus BX5 light microscopy linked to the Olympus DP26 camera and a personal computer with the CellSens Standart application. The epilithic microalgae characteristics were then analyzed descriptively using a microalgae identification book (Naselli-Flores \& Barone, 2009; Barsanti \& Gualtieri, 2014; Kaštovský et al., 2019).

Microalgae were identified based on the $18 \mathrm{~S}$ rRNA gene sequence (for eukaryotic) and 16S rRNA gene sequence (for prokaryotic). Firstly, as much as $10 \mathrm{ml}$ of microalgae culture was centrifuged for 4 minutes at $3000 \mathrm{rpm}$, a temperature below $10^{\circ} \mathrm{C}$. Genomic DNA was extracted using the Genomic DNA mini kit (Plant) Geneaid, following Genetica Science manufacturing protocol. Amplification was performed using $18 \mathrm{~S}$ rRNA primers, 18SF, and 18SR for eukaryotic microalgae (Tale et al., 2014). A partial gene sequence of $16 \mathrm{~S}$ rRNA was amplified using universal primers, Forward 27F Algae, and Reverse 1510R for prokaryotic microalgae (Marsh \& Nakatsu, 2014). The PCR composition was $12.5 \mu \mathrm{l}$ GoTag ${ }^{\circledR}$ Green Master Mix, $10 \mu$ l Nuclease Free Water (NFW), $0.5 \mu \mathrm{l}$ primer, $0.5 \mu \mathrm{l}$ DMSO, and $1 \mu \mathrm{l}$ DNA template. The PCR condition includes pre denaturation at $94^{\circ} \mathrm{C}$ for five minutes, 35 cycles of 
denaturation at $94^{\circ} \mathrm{C}$ for one minute, annealing at $63^{\circ} \mathrm{C}$ (for eukaryotic) and $55^{\circ} \mathrm{C}$ (for prokaryotic) for one minute, and extension at $72^{\circ} \mathrm{C}$ for one minute, then final extension at $72^{\circ} \mathrm{C}$ for 10 minutes, and storage at $4^{\circ} \mathrm{C}$ (Ma et al., 2008; Tale et al., 2014).

The PCR products were visualized on $1 \%$ agarose gel under UV-transilluminator using Mupid Electrophoresis. Then, the gene fragment was sequenced by Macrogen. inc. The DNA sequence similarities were analyzed using the BLASTN program on the NCBI database server (http://www. ncbi.nlm.nih.gov/BLAST). A phylogenetic tree was constructed using Neighbor-Joining (NJ), 1000 bootstrap welding methods with the application of the Molecular Evolutionary Genetics Analysis (MEGA) program (Kumar et al., 2018).

\section{RESULTS AND DISCUSSION}

We successfully isolated and purified nine isolates of epilithic microalgae from the biofilm on Borobudur Temple stone during this study. Based on isolates' morphological characteristics under a light microscope, the isolates identified to the division Chlorophyta and division Cyanophyta. Among the nine isolates, six isolates belong to Chlorophyta (or green algae) division, and three isolates belong to the Cyanophyta division. The isolates code belongs to the Chlorophyta division were M18-BR1, M18-BR2, M18-BR5, M18-BR13, M18-BR16, and M18-BR20, while the isolates code belongs to Cyanophyta were M18-BR7, M18-BR8, and M18-BR12 (Figure 1).

Molecular identification was carried out to support the identification of morphology and determine which types of isolates to the species level. Six isolates were identified based on the $18 \mathrm{~S}$ rRNA gene sequence, and three isolates were identified based on the 16S rRNA gene sequence. The 18S rRNA gene sequence was determined, and BLAST analysis was performed, which confirmed that the isolate M18-BR1 has similarities with Ankistrodesmus falcatus, M18-BR2 has similarities with Tetraselmis cordiformis, M18-BR5 has similarities with Pseudendoclonium arthropyreniae, M18-BR13 has similarities with Messastrum gracile, M18-BR16 has similarities Stigeoclonium aestivale, and M18-BR20 has similarities with Scenedesmus acuminatus. The similarity values of these isolates were between 99.06-99.68 of the closest strain type (Table 1.).

Three isolates (M18-BR7, M18-BR8, and M18BR12) were identified based on the 16S rRNA gene. These isolates have similarities with Anabaena cylindrica (M18-BR7), Nostoc gelatinosum (M18-BR8), and Oscillatoria limnetica (M18-BR12). The isolates have a homology percentage of 100, $99.31 \%$, and $99.04 \%$ of the closest strain type (Table 2).

The Neighbor-Joining method's phylogeny tree construction was made with 1000 bootstrap replications in the Kimura 2 Parameter model, to
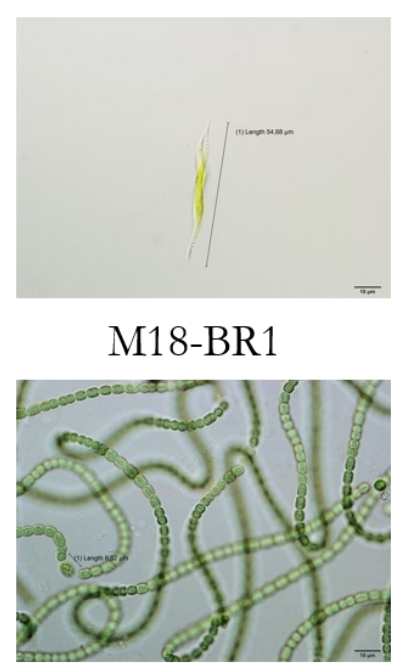

M18-BR7

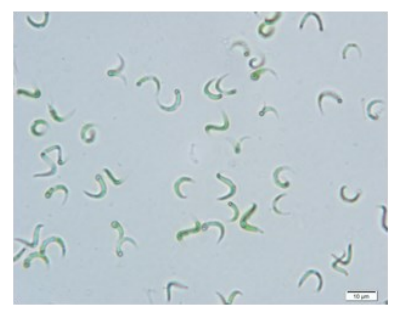

M18-BR13

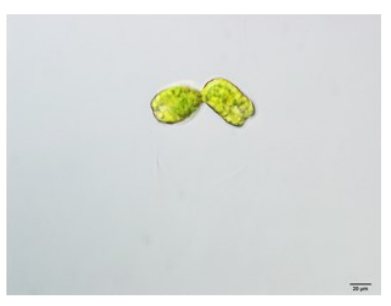

M18-BR2

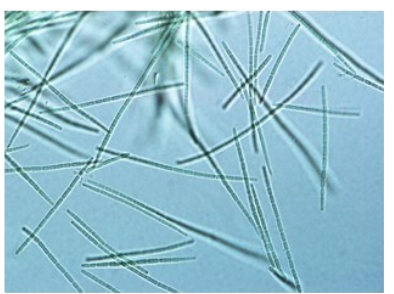

M18-BR8

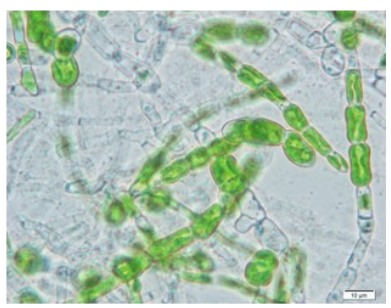

M18-BR16

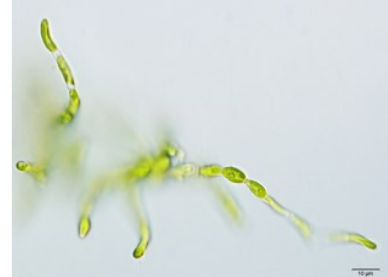

M18-BR5

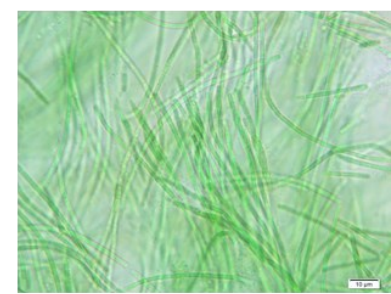

M18-BR12

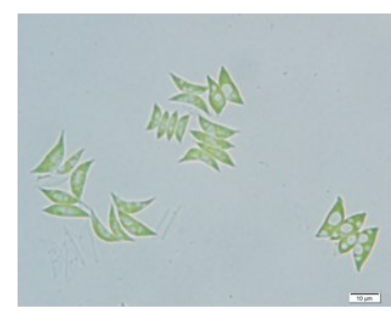

M18-BR20

Figure 1. Microscopic photographs of epilithic microalgae in the biofilm of the Borobudur Temple stone. 
Table 1. Identification result of epilithic microalgae isolates based on 18S rRNA gene.

\begin{tabular}{lclc}
\hline \multicolumn{1}{c}{ Isolate code } & $\begin{array}{c}\text { Number of } \\
\text { nucleotides }\end{array}$ & \multicolumn{1}{c}{ Sequence result } & $\begin{array}{c}\text { Percentage of } \\
\text { homology }\end{array}$ \\
\hline M18-BR1 & 609 & Ankistrodesmus falcatus (MK159026.1) & 99.06 \\
M18-BR2 & 610 & Tetraselmis cordiformis CCAC 0051 (MK460468.1) & 99.93 \\
M18-BR5 & 601 & Pseudendoclonium arthropyreniae SAG467-2 (MF034609.1) & 99.66 \\
M18-BR13 & 609 & Messastrum gracile CCMA UFSCar 622 (KT833593.1) & 99.34 \\
M18-BR16 & 624 & Stigeoclonium aestivale EP SAG477-20 (KU948222.1) & 99.64 \\
M18-BR20 & 606 & Scenedesmus acuminatus (AB037088.1) & 99.68 \\
\hline
\end{tabular}

Table 2. Identification result of epilithic microalgae isolates based on 16s rRNA gene.

\begin{tabular}{lclc}
\hline \multicolumn{1}{c}{ Isolate code } & $\begin{array}{c}\text { Number of } \\
\text { nucleotides }\end{array}$ & \multicolumn{1}{c}{ Sequence result } & $\begin{array}{c}\text { Percentage of } \\
\text { homology }\end{array}$ \\
\hline M18-BR7 & 1377 & Anabaena cylindrica NIES19 (AF247592.1) & 100 \\
M18-BR8 & 1390 & $\begin{array}{l}\text { Nostoc sp. Leptogium gelatinosum cyanobiont } \\
\text { (DQ185232.1) }\end{array}$ & 99.31 \\
M18-BR12 & 1381 & \begin{tabular}{l} 
Oscillatoria limnetica MR1 (AJ007908.1) \\
\hline
\end{tabular}
\end{tabular}

emphasize the identification process of the Basic Local Alignment Search Tool (BLAST). A phylogenetic tree showed that microalgae isolates were affiliation to nine species, the results obtained as shown in Figures 2 and 3.

Ankistrodesmus falcatus is a species of Chlorophyta in the family Selenastraceae. It is needle -like in shape, with gradually tapering ends. As seen in the morphology of the M18-BR1 isolate in Figure 1. Cells mostly of four arranged in cruciate flocky mucilaginous groups could be two to many cells in a colony. M18-BR2 isolate was identified as Tetraselmis cordiformis which belongs to the phylum Chlorophyta. These isolates are characterized by chloroplasts of intense green color, their marked cell bodies, the presence of pyrenoids in the chloroplasts, and skeletal walls produced by scales. Isolates M18-BR5 has a green appearance of cell morphology, unipolar or bipolar germination, the irregular shape of the filament, with branching cylinder attached to the surface, can be split into different directions and has a parietal chloroplast with a pyrenoid. Molecularly, this isolate was identified as Pseudendoclonium arthropyreniae.

M18-BR13 was identified as Messastrum gracile which belongs to phylum Chlorophyta in the family Selenastraceae. Morphologically, the cells are narrow, fusiform to semilunate in shape, the ends gradually tapered, curved. Colonies are solitary or multicellular with irregularly separated cells. There is one parietal chloroplast with a cell wall covered by a thin layer of diffuse mucus. M18-BR16 isolate has morphological characteristics of branched filamentous thalli, without rhizoid. The filamentous cells are cylindrical or spherical, containing chloroplasts of the parietal plate with pyrenoids. The branches are unilateral or alternating, not opposite, ending in sharp cells or hairs, with a thick gelatinous sheath. This isolate was identified as Stigeoclonium aestivale. InaCC M131 isolate is a green cell, with an elliptical and spindle shape, and has chloroplasts containing pyrenoid. This isolate was identified as Scenedesmus acuminatus.

In this study, we are showing for the first time the biodiversity of epilithic microalgae on the biofilm of Borobudur Temple Stone, identified by morphological and molecular traits. Chlorophyta was the dominant taxa from the biofilm on Borobudur Temple stone, with six genera (Ankistrodesmus, Tetraselmis, Pseudendoclonium, Messastrum, Stigeoclonium, and Scenedesmus). The genera are mostly soil algae. Biological colonization of the stone containing micro-organisms such as microalgae can originate from the surrounding soil, contaminating the stone after excavation. Also, stone inoculation can occur due to increased infiltration of groundwater and windblown dendrites. According to Soares et al. (2019), the Chlorophyta division is a cosmopolitan type that is easy to breed and adapt. They often occur in stone monuments and building stone walls, which are anthropogenic surfaces. Some of them are tolerant of harsh environmental conditions, including temperature fluctuations. This trait also causes Chlorophyta to be more diverse than other groups.

Two orders from the Cyanophyta group were also found from the biofilm in Borobudur temple stone, namely Nostocales and Oscillatoriales. Anabaena and Nostoc included in the Nostocales group were isolated from samples examined from the Borobudur temple stone's biofilm. Anabaena has 


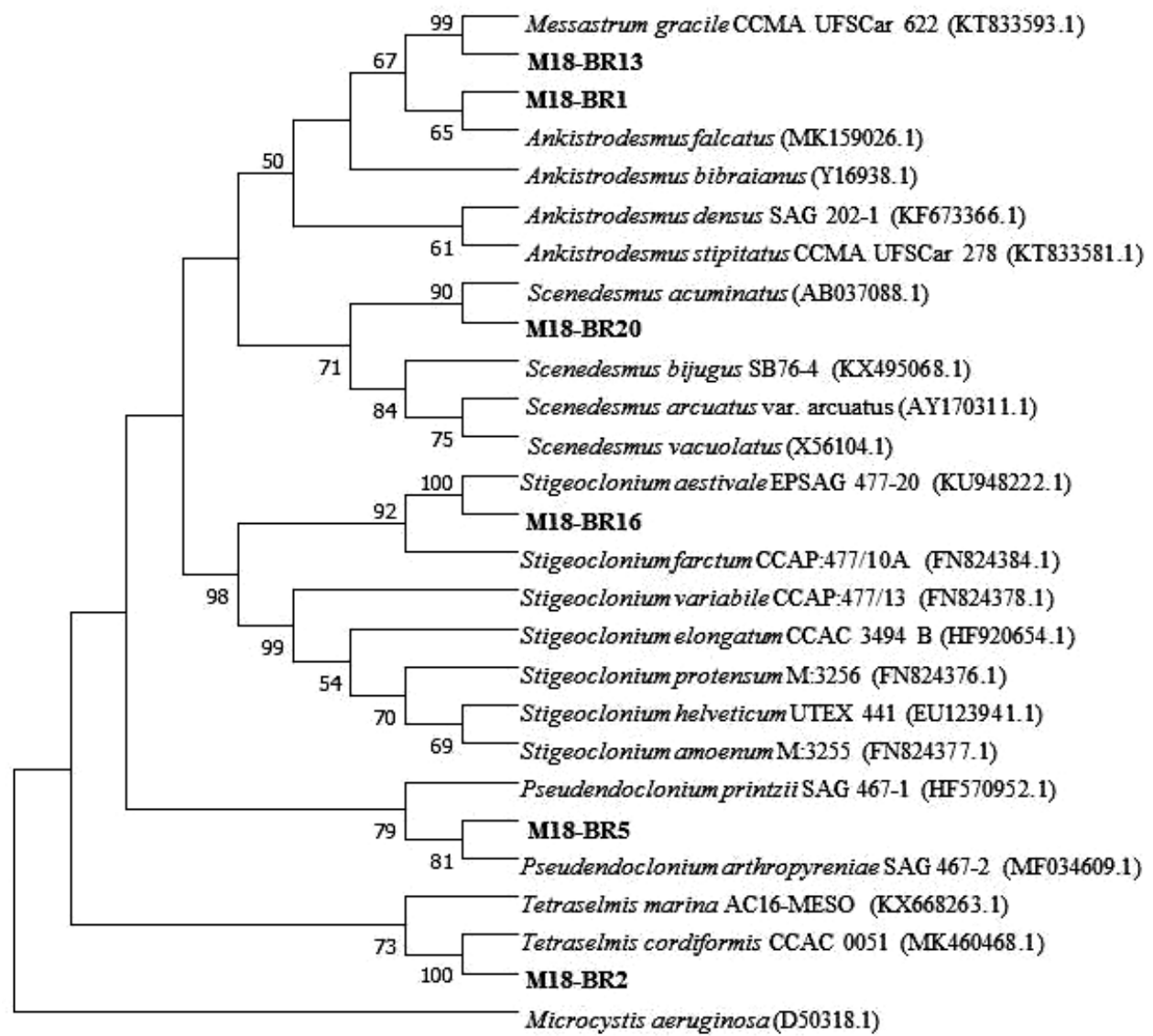

Figure 2. The phylogenetic tree of six selected epilithic microalgae isolates based on $18 \mathrm{~S}$ rRNA gene sequences.

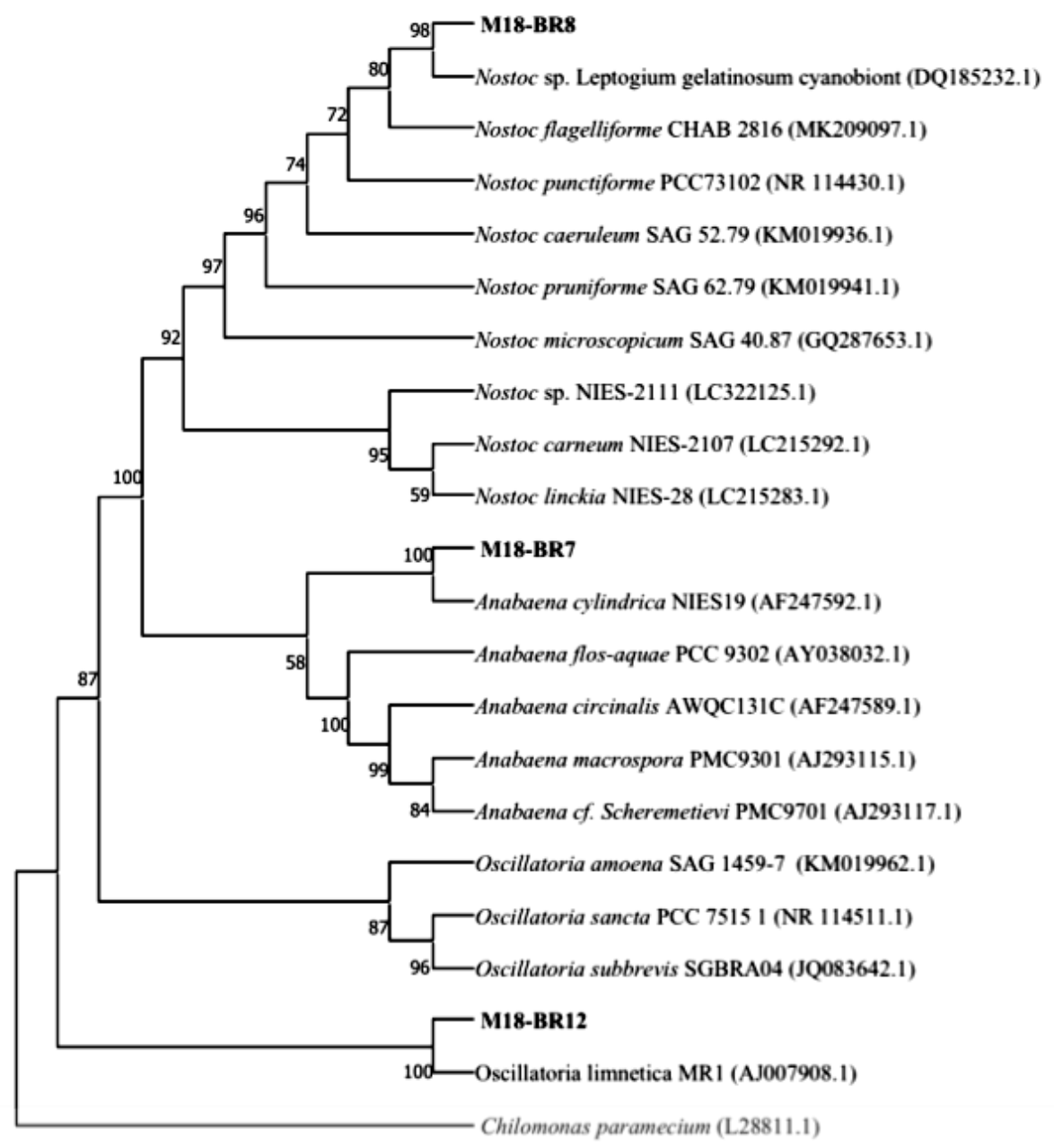

Figure 3. The phylogenetic tree of three selected epilithic microalgae isolates based on 16S rRNA gene sequences. 
characteristic filaments with a long chain of vegetative cells ranging from square to round, or cylindrical. Heterocyst forms with a slightly higher length compared to vegetative cells. Nostoc also has cells arranged in beaded chains. Nostoc also has cells arranged in bead chains in the form of unbranched filaments. There are heterocysts with a filamentous structure that is twisted and folded by itself to form a spherical structure. Kaštovský et al. (2019) stated that epilithic Cyanophyta, such as Nostocales have thick outer envelopes and protective pigments to survive extreme environmental conditions such as cold, hot, and dry stone surfaces along with cryptoendollithic lichens, fungi, and bacteria. The Oscillatoria limnetica identified in this study completely lacks a sheath, and the cells may contain small vacuoles. The cells are typically considerably longer than broad, although the length to width ratio varies. Average filament length is quite steady across seasons. Occasionally the filaments are slightly curved, but never tightly coiled. The cells touch each other but are not closely joined as in most Oscillatoria species. Adhikary (2000) and Pandey (2011) reported that the Cyanophyta group belonging to the genera Gloeocapsa, Lyngbya, Oscillatoria, and Tolypothrix is the main component of the biofilm. These epilithic microalgae are enveloped by a colored sheath layer and occurred binding with finely textured soil particles on the temple stones. The microalgae communities that inhabit these stones are filamentous microalgae that can induce carbonate formation and cement deposition. In the present study, the Cyanophyta that colonized the temple stones were dominated by filamentous forms such as Oscillatoria, Nostoc, and Anabaena.

According to several studies, Chlorophyta and Cyanophyta can develop easily on stone surfaces because of their photoautotrophic nature. They are considered pioneering inhabitants of stone colonization, giving rise to colored patinas and incrustations (Tomaselli et al., 2000; Vázquez-Nion et al., 2016; Villa et al., 2016; Popović et al., 2018; Gallego-Cartagena et al., 2020). The epilithic microalgae identified in this study are known to have a water reservoir in the form of a gelatinous sheath, bound by a strong molecular force, thus allowing the microalgae to colonize stone even in dry conditions. This sheath causes adhesion to the substrate. Sometimes the sheath can be pigmented and colored, which is an expression of various ecology and environmental adaptation stages, such as light intensity, temperature, nutrient availability, and cell age. Reduction in chlorophyll and phycocyanin, as well as increased carotenoids under low nitrogen conditions, can cause the epilithic microalgae to turn yellow-brown. Colored patinas and incrustations because of epilithic microalgae cause aesthetic damage to the temple building (Wynn-Williams et al., 2002; Mayer, Dubinsky, \& Iluz, 2016; Sonina et al., 2018).

Many factors can cause the high number of taxa contained in the biofilm on the Borobudur Temple stone. One of them is the physicochemical properties of rocks that support the formation of photosynthetic communities such as epilithic microalgae that live in it, especially light, which affects the total community biomass. The availability of water also determines the successful colonization of green algae and Cyanophyta and allows subaerial biofilms to be formed by micro-organisms. According to Young et al. (2008) and Pinheiro et al. (2019), the population or community of immobilized micro-organisms on the surface of a stone, including green algae and Cyanophyta, can live in biofilms because biofilms can introduce large amounts of water into their structures so that the humidity and temperature balance is maintained. They play a role in binding cells to the substrate (adhesion) and cells to other particles together (cohesion).

Epilithic microalgae from biofilms in Candi rocks can be considered deteriogenic, because patinas that produce various colors can be aesthetically damaging (Javaherdashti et al., 2009). Macedo et al. (2009) stated that the inhibition of epilithic microalgae colonization reduces the growth and heterotrophicity of fungi and bacteria and supports the accepted colonization sequence. These photosynthetic micro-organisms can provide nutrients for other communities' growth through the accumulation of the resulting biomass. They contribute to stone breaking directly and through synergistic interactions with heterotrophic microorganisms such as fungi and bacteria. So the isolation and identification of epilithic microalgae are very important for further research on the control and prevention of biodeteriogenic processes.

\section{CONCLUSION}

Chlorophyta was the dominant taxa from the biofilm on Borobudur Temple stone, consisting of Ankistrodesmus falcatus, Tetraselmis cordiformis, Pseudendoclonium arthropyreniae, Messastrum gracile, Stigeoclonium aestivale, and Scenedesmus acuminatus.. Three species from the Cyanophyta group were also found, namely Anabaena cylindrica, Nostoc gelatinosum, and Oscillatoria limnetica. This study may help evolve a managerial plan for preventing the growth of epilithic microalgae in exposed temple stones and historic buildings to prevent damage. The isolated epilithic microalgae were then preserved and stored in the Indonesian Cultural Collection (InaCC) for further study on the ecology and physiology of 
certain species of this micro-organism to understand their role in the process of stone colonization and biodeterioration.

\section{ACKNOWLEDGMENTS}

Microalgae used in this study were isolated and identified as part of the Research project (DIPA) in the Research Centre for Biology, LIPI. The author acknowledges the support of the Borobudur Conservation Office for giving permission and help during collected samples.

\section{REFERENCES}

Adhikary, S. P., 2000, Epilithic cyanobacteria on the exposed rocks and walls of temples and monuments of India, Indian Journal of Microbiology 40, 67-81.

Anderson, R. A., 2005, Algal Culturing Techniques, 1st Edition, Elsevier Academic Press Phycological Society of America.

Banindro, B. S., 2017, Borobudur Temple pre and post colonial era, DeKaVe 8(1), 1-10.

Barsanti, L. \& Gualtieri, P., 2014, 'Algal Culturing', in Algae, pp. 221-266, CRC Press, Italy.

Bertuzzi, S. et al., 2017, Heat shock treatments for the control of lithobionts: A case study with epilithic green microalgae, International Biodeterioration and Biodegradation 123, 236-243.

Gallego-Cartagena, E. et al., 2020, A comprehensive study of biofilms growing on the built heritage of a Caribbean industrial city in correlation with construction materials, International Biodeterioration and Biodegradation 123, 236-243.

Garside, P., 2010, 'Cultural heritage microbiology. Fundamental studies in conservation scienceseccion III: Textiles', in Cultural Heritage Microbiology. Fundamental Studies in Conservation Science, p. 348, ASM Press, Washington D.C.

Gunarto, H., 2007, Preserving Borobudur's narrative relief wall of UNESCO Cultural World Heritage, RCAPS Occasional Paper 7(5),1-13.

Javaherdashti, R. et al., 2009, On the impact of algae on accelerating the biodeterioration/ biocorrosion of reinforced concrete: A mechanistic review, European Journal of Scientific Research 36, 394-406.

Kaštovský, J. et al., 2019, 'Algae', in Biodiversity of Pantepui: The Pristine 'Lost World' of the Neotropical Guiana Highlands, pp. 470, Academic Press Elsevier, Cambridge, United States.

Keshari, N. \& Adhikary, S. P., 2013, Characterization of cyanobacteria isolated from biofilms on stone monuments at Santiniketan, India, Biofouling 29(5), 25-536.
Khoirunnisa, S. A., Warsono, H. \& Suryaningsih, M., 2014, Kinerja pemerintah dalam rehabilitasi dan rekonstruksi Kawasan Rawan Bencana (KRB ) di Kabupaten Magelang [Government performance in the rehabilitation and reconstruction of Disaster-Prone Areas (KRB) in Magelang Regency], Journal of Public Policy and Management Review 3(3), 141-149.

Kumar, S. et al., 2018, MEGA X: Molecular evolutionary genetics analysis across computing platforms, Molecular Biology and Evolution 35(6), 1547-1549.

Ma, R. et al., 2008, Identification and phylogenetic analysis of a bacterium isolated from the cloaca of Chinese alligator, African Journal of Biotechnology 7(13), 2128-2133.

Macedo, M. F. et al., 2009, Biodiversity of cyanobacteria and green algae on monuments in the Mediterranean Basin: An overview, Microbiology 155(11), 3476-3490.

Marsh, T. L. \& Nakatsu, C. H., 2014, 'Analysis of microbial communities with denaturing gradient gel electrophoresis and terminal restriction fragment length polymorphism', in Methods for General and Molecular Microbiology, Third Edition, pp. 909-923, ACM Press, Washington D.C.

Matteucci, E. et al., 2019, Lichens and other lithobionts on the carbonate rock surfaces of the heritage site of the tomb of Lazarus (Palestinian territories): diversity, biodeterioration, and control issues in a semiarid environment, Annals of Microbiology 69, 1033-1046.

Mayer, D., Dubinsky, Z. \& Iluz, D., 2016, Light as a limiting factor for epilithic algae in the supralittoral zone of littoral caves, Frontiers in Marine Science 3, 1-4.

Nakajima, M., Hokoi, S. \& Ogura, D., 2015, Relationship between environmental conditions and algal growth on the exterior walls at Kusyo Myojin Shrine, Ninna-Ji Temple, Journal of Environmental Engineering (Japan) 80(713), 574-582.

Naselli-Flores, L. \& Barone, R., 2009, 'Green Algae', in Encyclopedia of Inland Waters, PP. 166-173, Academic, Boston, London.

Pandey, V. D., 2011, Epilithic cyanobacteria occurring on the temples of Uttarakhand, India, Plant Archives 11(2), 1057-1060..

Pinheiro, A. C. et al., 2019, Limestone biodeterioration: A review on the Portuguese cultural heritage scenario, Journal of Cultural Heritage 36, 275-285. 
Popović, S. et al., 2018, Diversity of Terrestrial Cyanobacteria Colonizing Selected Stone Monuments in Serbia, Studies in Conservation 63 (5), 292-302.

Putri, A. L., Purbani, D.C. \& Habibi, M., 2020, Isolation and identification of Actinomycetes associated with moss on the surface of the Borobudur temple stone, Biosaintifica 12(1),1020.

Salazar, N. B., 2018, 'Indonesia's World Heritage', in Encyclopedia of Global Archaeology, PP. 1-6, Springer, Chambrige.

Soares, F. et al., 2019, Structural diversity of photoautotrophic populations within the UNESCO site "Old Cathedral of Coimbra" (Portugal), using a combined approach, International Biodeterioration and Biodegradation 140, 9-20.

Song, M.-A., Kim, O.-J. \& Lee, O.-M., 2012, The distribution and ecological factors of aerial algae inhabiting stoneworks in Korea, Algae 27 (4), 283-294.

Sonina, A. V. et al., 2018, Comparative study of structural and ecophysiological features of lichens of different ecological groups in rocky forest communities of northernmost boreal zone (Karelia, Russia), Czech Polar Reports 8(2), 186-197.

Tale, M. et al., 2014, Isolation and characterization of microalgae for biodiesel production from Nisargruna biogas plant effluent, Bioresource Technology 169, 328-335.
Tomaselli, L. et al., 2000, Biodiversity of photosynthetic micro-organisms dwelling on stone monuments, in International Biodeterioration and Biodegradation 46(3), 251-258.

Vázquez-Nion, D. et al., 2016, Subaerial biofilms on granitic historic buildings: microbial diversity and development of phototrophic multispecies cultures, Biofouling 32(6), 657-669.

Villa, F. et al., 2016, Subaerial biofilms on outdoor stone monuments: Changing the perspective toward an ecological framework, BioScience 66 (4), 285-294.

Voûte, C. \& Voute, C., 1973, The restoration and conservation project of Borobudur Temple, Indonesia. Planning: Research: Design, Studies in Conservation 18(3), 113-130.

Wynn-Williams, D. D. et al., 2002, Pigmentation as a survival strategy for ancient and modern photosynthetic microbes under high ultraviolet stress on planetary surfaces, International Journal of Astrobiology 1(1), 39-49.

Young, M. E. et al., 2008, Development of a biocidal treatment regime to inhibit biological growths on cultural heritage: BIODAM, Environmental Geology 56, 631-641.

Yulianto, F. et al., 2013, Extracting the damaging effects of the 2010 eruption of Merapi volcano in Central Java, Indonesia, Natural Hazards 66, 229-247. 